\title{
STRUKTUR PERCAKAPAN GURU DENGAN SISWA DALAM INTERAKSI PEMBELAJARAN BAHASA INDONESIA
}

\section{THE STRUCTURE OF TEACHERS WITH STUDENT'S CONVERSATION IN INDONESIAN LANGUAGE TEACHING INTERACTION}

\author{
Maria Rosalinda Talan \\ Universitas Timor \\ maria_rosalindatalan@yahoo.co.id
}

\begin{abstract}
Abstrak
Kurikulum 2013 merupakan penyempurnaan pola pikir dari kurikulum sebelumnya yang mengharuskan siswa terlibat aktif dalam pembelajaran. Salah satu aktivitas fisik siswa yang diharapkan dalam pembelajaran Bahasa Indonesia adalah aktif berbicara atau aktif dalam percakapan di kelas. Oleh karena itu, penelitian ini bertujuan mendeskripsikan struktur percakapan guru dengan siswa dalam interaksi pembelajaran Bahasa Indonesia. Jenis penelitian ini adalah deskriptif kualitatif. Teknik pengumpulan data dilakukan dengan teknik rekam dan catat. Teknik analisis data dilakukan dengan teknik heuristik. Hasil penelitian menunjukkan, bahwa dalam interaksi pembelajaran Bahasa Indonesia, terdapat struktur percakapan yakni 1) gilir bicara yang terjadi karena adanya kesempatan untuk bertutur, 2) jeda (panjang dan pendek) yang terjadi akibat tidak adanya respons balik berupa tuturan dan penutur merasa ragu dalam menyampaikan pesan. 3) overlaps yang terjadi karena tuturan atau penggunaan unsur lingual yang sama, 4) backchannel yang terjadi karena ada pemahaman dan penerimaan atau persetujuan terhadap tuturan, dan 5) pasangan ajesensi yang terjadi karena adanya ucapan salam, pertanyaan, dan permohonan.
\end{abstract}

Kata Kunci: struktur percakapan, guru dan siswa, dan interakasi pembelajaran

\begin{abstract}
The 2013 curriculum is a revision of ideas derived from the previous curriculum where students' active performance is imposed in study. One of students' physical activities expected from Indonesian language instruction is speaking or actively involving in class conversation. Therefore, this study aims at describing the structure of teachers and students' conversation in Indonesian language teaching interaction. This is a descriptive qualitative study. The techniques of data obtaining are recording and taking notes, and the technique of data analysis is heuristic. The result of this study shows the conversation structures in Indonesian language instruction are 1) turn taking occurred when there is a chance to speak. 2) pausing (long and short) occurred since there is no responsse and when there is hesitation in delivering messages. 3) overlapping occurred since there is a similar utterance or language element produced simultaneously. 4) backchanneling occurred since there are comprehension and acceptance or agreement towards utterances, and 5) adjacency pairs occurred since there are greetings, questions, and requests.
\end{abstract}

Keywords: conversation structure, students and theachers interaction in teaching.

\section{PENDAHULUAN}

Dalam setiap aspek kehidupan, manusia tidak terlepas dari percakapan. Setiap orang dengan leluasa berinteraksi dengan sesamanya melalui percakapan untuk memenuhi kebutuhan hidupnya. Richardt (dalam Purba, 2002:93) menyatakan bahwa percakapan adalah tuturan dengan cara berhadapan muka antara dua orang atau lebih. Artinya 
percakapan hanya sebatas interaksi secara lisan antara orang yang berbicara (penutur) dengan orang yang diajak berbicara (petutur) yang membahas suatu hal dalam satu waktu tertentu. Namun, sering ditemui adanya proses interaksi antara satu orang atau lebih di media cetak atau elektronik berupa tulisan. Pada dasarnya, proses interaksi tersebut juga dapat dikatakan sebagai percakapan karena sebenarnya hal itu merupakan perwujudan dari percakapan lisan. Percakapan berupa tulisan dapat dijumpai pada teks drama, novel, cerpen, dan percakapan lain seperti chatting di media sosial elektronik.

Suatu percakapan mengandung struktur. Struktur percakapan disebut juga organisasi percakapan. Dalam struktur percakapan terdapat enam bagian diantaranya gilir bicara, overlaps, jeda, bachannel, dan pasangan ajesensi (Yule, 2006:121). 1) Gilir bicara merupakan proses pergantian peran antara penutur dan petutur dalam suatu percakapan yang tidak terdapat rambu-rambu atau aturan. Artinya, setiap pemeran percakapan mempunyai hak yang sama untuk bertutur. Pada saat penutur berbicara dan tidak dapat menyesuaikan kontrol, maka petutur berhak mendapatkan gilir bicara tersebut. 2) Jeda merupakan kesenyapan dalam percakapan yang memungkinkan menandai adanya gilir bicara. Jeda dalam percakapan memiliki tiga bentuk yaitu jeda pendek, sedang, dan panjang. Jeda pendek merupakan kesenyapan pendek sebagai bentuk keragu-raguan dan jeda panjang merupakan kesenyapan panjang. Jeda dalam percakapan memiliki beberapa kegunaan yakni jeda yang digunakan sebelum beralihnya gagasan, menandaskan, sesuai tuntutan keadaan dan mengundang tanggapan. 3) Overlaps adalah keadaan penutur dan petutur yang berbicara pada waktu bersamaan. Overlaps menyiratkan makna bahwa dalam percakapan yang dinamakan overlaps jika terjadi tumpang tindih tuturan antara penutur dan petutur dalam waktu yang bersamaan secara alami atau tidak dibuat-buat. 4) Backchannel merupakan respons yang diharapkan penutur kepada petutur (dapat berupa gerakan tubuh atau isyarat). Respons itu bisa berupa kata-kata seperti "ah-ha”, "uh-huh", "yeah”, anggukan, senyuman, ekspresi muka dan juga bisa gerak isyarat. Dengan adanya backchannel, penutur merasa bahwa petutur cukup memahami pembicaraannya. 5) Pasangan ajesensi atau pasangan berdampingan adalah pola yang terjadi secara otomatis dalam percakapan dan selalu terdiri atas dua bagian yang diucapkan oleh pihak yang berbeda. Schegloff dan Sacks (dalam Purwoko, 2008: 88) pasangan ajesensi merupakan rentetan dua ucapan yang berpasangan, dihasilkan oleh penutur yang berbeda, ada bagian pertama dan kedua, serta memiliki memiliki jenis sehingga bagian pertama selalu membutuhkan bagian yang kedua. Dalam pasangan ajesensi, tuturan pertama selalu dengan cepat menciptakan tuturan yang kedua karena merupakan pasangan yang otomatis, misalnya ucapan salam ada pasangannya untuk menjawab salam dan tuturan yang berupa pertanyaan yang selalu ada pasangannya yaitu sebuah jawaban .

Penelitian-penelitian terdahulu telah mengkaji beberapa bagian dari struktur percakapan. Penelitian Trahutami (2012) yang judul "Struktur Pola Alih Tutur pada Percakapan Anak-Anak" hanya memfokuskan pada salah satu bagian dari struktur percakapan yakni pola alih tutur/gilir bicara. Demikian pula penelitian yang dilakukan oleh Matyawati (2014) yang berjudul "Pasangan Berdampingan (Adacency Pairs) dalam Lomba Ngapeh di Kutai Kartanegara. Penelitiannya hanya berfokus pada satu bagian dari struktur percakapan yakni pasangan berdampingan (adacency pairs). Padahal, selain alih tutur/gilir 
bicara dan pasangan berdampingan (adacency pairs) masih ada bagian lain dari struktur percakapan yakni jeda, backchannel, dan overlaps. Dengan demikian, peneliti tertarik untuk melakukan penelitian tentang struktur percakapan yang mengkaji secara lengkap mengenai gilir bicara, jeda, backchannel, dan overlaps dan pasangan ajesensi/pasangan berdampingan.

Percakapan juga terjadi dalam interaksi pembelajaran di kelas. Guru dengan siswa saling berinteraksi melalui percakapan untuk mencapai tujuan pembelajaran yang telah ditetapkan. Percakapan guru dengan siswa menggambarkan pola interaksi tertentu dalam suatu pembelajaran. Pola interaksi yang paling baiik menurut pandangan Cara Belajar Siswa Aktif (CBSA) adalah pola interaksi multiarah (Sudiana, 2005:17). Pola ini memberikan ruang yang signifikan kepada siswa seluas-luasnya untuk terlibat aktif dalam interaksi pembelajaran. Hal ini memberikan peluang adanya struktur percakapan dalam interaksi pembelajaran.

Interaksi pembelajaran dalam kurikulum 2013 sangat mendukung pandangan CBSA. Kurikulum 2013 menawarkan berbagai model pembelajaran Bahasa Indonesia yang dapat mengakomodasi siswa untuk mencari tahu sendiri tentang materi yang sedang dipelajari misalnya model pembelajaran Discovery Based Learning, Problem Based Learning, Project Based Learning, dan lain-lain. Model-model pembelajaran ini memberikan peluang percakapan yang lebih signifikan karena siswa diberi kesempatan berinteraksi secara leluasa baik dengan guru maupun dengan sesama siswa dalam interaksi pembelajaran. Dengan demikian, peneliti tertarik untuk meneliti struktur percakapan guru dengan siswa yang terjadi dalam interaksi pembelajaran Bahasa Indonesia di SMK se-Kota Kefamenanu.

Berdasarkan uraian di atas, penelitian ini bertujuan mendeskripsikan struktur percakapan guru dengan siswa yang terjadi dalam interaksi pembelajaran Bahasa Indonesia di SMK se-Kota Kefamenanu. Struktur perakapan yang dimaksud meliputi gilir bicara, overlaps, jeda, bachannel, dan pasangan ajesensi.

\section{METODE PENELITIAN}

Data dalam penelitian ini adalah data verbal berupa tuturan guru dengan siswa yang menunjukan adanya gilir bicara, overlaps, jeda, backbannel, dan pasangan ajesensi. Data tersebut didapatkan pada saat guru dengan siswa melakukan percakapan dalam pembelajaran Bahasa Indonesia di kelas. Sumber data dalam penelitian ini yaitu guru dan siswa SMK se-Kota Kefamenanu. Pemilihan sumber data tersebut didasarkan bahwa siswa SMK merupakan siswa yang aktif secara fisik karena terbiasa melakukan aktivitas motorik. Oleh karena itu, salah satu aktivitas fisik seperti berinteraksi dengan guru di dalam kelas juga dimungkinkan terjadi. Adanya interaksi antara guru dengan siswa SMK dalam interaksi pembelajaran Bahasa Indonesia memberikan peluang adanya struktur percakapan.

Teknik yang digunakan untuk mengumpulkan data dalam penelitian ini adalah teknik rekam dan teknik catat. Teknik rekam digunakan untuk merekam percakapan guru dengan siswa selama interaksi pembelajaran berlangsung. Teknik catat digunakan pada saat alat perekam sudah dimatikan, namun masih ada tuturan guru dengan siswa yang mengandung data. Teknik yang digunakan untuk menganalisis data adalah teknik heuristik. Teknik heuristik merupakan teknik yang digunakan peneliti untuk menafsirkan unsur lingual tertentu atau tuturan. Pada mulanya, tuturan dari guru dengan siswa dijadikan masalah, 
ditentukan hipotesis sementara, diuji berdasarkan konteks di lapangan, lalu diambil kesimpulan.

\section{HASIL DAN PEMBAHASAN}

\section{Hasil Penelitian}

\section{a. Gilir Bicara}

Gilir bicara merupakan proses pergantian peran antara penutur dan petutur dalam suatu percakapan yang tidak terdapat rambu-rambu atau aturan. Artinya, setiap pemeran percakapan mempunyai hak yang sama untuk bertutur. Gilir bicara dalam percakapan guru dengan siswa dalam interaksi pembelajaran Bahasa Indonesia tampak pada data berikut.

Guru : "Apa itu puisi??"

Siswa : "Puisi adalah salah satu karya sastra yang menggunakan bahasa yang

Guru : indah."

$$
\text { "Ya, bagus." }
$$

Konteks percakapan di atas terjadi pada saat kegiatan inti pembelajaran. Guru menanyakan pengertian puisi kepada siswa. Dalam hal ini guru memberikan kesempatan kepada siswa untuk menjawab pertanyaannya. Kesempatan yang diberikan guru tampak pada diamnya guru setelah mengajukan pertanyaan kepada siswa. Pada saat itu, siswa langsung mengambil kesempatan yang diberikan guru untuk menjawab pertanyaan tersebut. Dari data di atas tampak terjadi pola gilir bicara dari guru—siswa—guru. Dengan demikian struktur percakapan ini termasuk dalam gilir bicara.

\section{b. Jeda}

Jeda merupakan kesenyapan dalam percakapan yang memungkinkan menandai adanya gilir bicara. Jeda dalam percakapan memiliki tiga bentuk yaitu jeda pendek, sedang dan panjang. Jeda pendek merupakan kesenyapan pendek sebagai bentuk keragu-raguan dan jeda panjang merupakan kesenyapan panjang. Jeda dalam percakapan guru dengan siswa dalam interaksi pembelajaran Bahasa Indonesia tampak pada data berikut.

1. Jeda Pendek

Guru : "Perbuatan buruk apa yang dilakukan Haji Saleh semasa hidupnya sehingga ia masuk neraka?"

Siswa : "Perbuatan buruk apa yang dilakukan Haji Saleh semasa hidupnya sehingga ia masuk neraka yaitu pertama ia tidak bekerja untuk menghidupi istrinyamaksudnya keluarganya. Kedua, dia tidak beramal dan tidak-dia tidak beramal dan hanya mementingkan dirinya saja".

Konteks percakapan di atas terjadi pada kegiatan inti pembelajaran. Pada saat itu, kelompok 1 yang baru selesai presentasi dan bertanya jawab dengan siswa antarkelompok. Kemudian, guru pun mengajukan pertanyaan kepada kelompok yang baru saja presentasi hasil diskusinya. Salah satu siswa langsung menjawab pertanyaan guru namun memiliki keragu-raguan di tengah tuturan. Keraguan-keraguan itu ditandai dengan tanda pisah. Jeda terjadi setelah menuturkan kata istrinya dan kata tidak. Hal ini menujukkan adanya jeda pendek (2 detik) dalam percakapan itu. 
2. Jeda Panjang

Guru : "Ada yang mau bertanya?" (15 detik)

Guru : "Kalau ada yang mau bertanya, silakan!” (10 detik)

Guru : "Tidak ada. Baik, Ibu akan mereview materi dari yang pertama sampai terakhir. Sebutkan ciri bahasa cerpen!"

Siswa : "Saya." (Seorang siswa mengancungkan tangan)

Konteks percakapan di atas terjadi pada saat kegiatan penutupan pembelajaran. Pada saat itu guru memberi kesempatan kepada siswa untuk bertanya tentang materi yang belum dipahami, namun siswa tidak memanfaatkan kesempatan itu. Oleh karena siswa tidak memanfaatkan kesempatan, muncullah jeda panjang pada tuturan guru setelah kata bertanya dan kata silakan. Hal ini menujukkan adanya jeda panjang (10-15 detik) dalam percakapan itu.

\section{c. Overlaps}

Overlaps adalah keadaan penutur dan petutur yang berbicara pada waktu bersamaan. Overlaps dalam percakapan guru dengan siswa dalam interaksi pembelajaran Bahasa Indonesia tampak pada data berikut.

Guru : "Nah, yang pertama tadi pengertian cerpen, yang kedua ciri-ciri cerpen, yang ketiga -unsur-unsur intrinsik-

Beberapa Siswa : --unsur intrinsik-

Guru : "dan yang keempat adalah -contoh cerpen-."

Beberapa Siswa : "—contoh cerpen-“"

Konteks percakapan di atas terjadi pada saat kegiatan akhir pembelajaran. Pada saat itu guru sedang mereview materi dari awal hingga akhir. Pada saat guru sedang berbicara, siswa ikut berbicara yaitu pada frasa unsur intrinsik dan kata contoh cerpen dalam waktu yang bersamaan. Dengan demikian, struktur percakapan ini termasuk overlaps.

\section{d. Backchanel}

Backechannel merupakan respons yang diharapkan penutur kepada petutur (dapat berupa gerakan tubuh atau isyarat). Backchannel dalam percakapan guru dengan siswa dalam interaksi pembelajaran Bahasa Indonesia tampak pada data berikut.

Guru : "Siapa yang bisa menjelaskan hakikat teks negosiasi?"

Siswa 1: (mengangkat tangan)

Guru : 'Silahkan Julio!'

Siswa 1: “Teks negosiasi adalah proses tawar-menawar

Guru : hmm (sambil mengganguk kepala)

Siswa1 : yang dilakukan oleh dua pihak untuk mencapai kesepakatan".

Guru : "Yah."

Konteks percakapan di atas terjadi pada kegiatan pembukaan pembelajaran yakni apersepsi. Pada saat itu guru menanyakan materi minggu lalu. Setelah guru bertanya, siswa langsung memberikan respons untuk menjawab pertanyaan guru. Di sela-sela jawaban yang diberikan siswa, guru memberikan respons "hmm" dan "yah" yang merupakan isyarat 
bahwa tuturan dari siswa tersebut diterima. Dengan demikian, struktur percakapan ini termasuk backhannel.

\section{e. Pasangan Ajesensi}

Pasangan ajesensi atau pasangan berdampingan adalah pola yang terjadi secara otomatis dalam percakapan dan selalu terdiri atas dua bagian yang diucapkan oleh pihak yang berbeda. Pasangan ajesensi dalam percakapan guru dengan siswa dalam interaksi pembelajaran Bahasa Indonesia tampak pada data berikut.

Siswa : "Siap hormat "selamat pagi ibu guru"

Guru : "Selamat pagi, silahkan duduk!"

Konteks percakapan di atas terjadi pada kegiatan pembukaan pembelajaran. Pada saat itu, guru masuk ke dalam kelas, lalu siswa menyambut kedatangan guru dengan memberikan salam kepada guru. Setelah siswa memberikan salam, tentu guru langsung merespons salam yang diberikan oleh siswa. Pemberian salam dan respons terhadap salam itu merupakan pasangan otomatis dalam percakapan. Dengan demikian, struktur percakapan ini termasuk pasangan ajesensi.

\section{Pembahasan}

Berdasarkan analisis data, ditemukan adanya struktur percakapan guru dengan siswa dalam interaksi pembelajaran Bahasa Indonesia di SMK se-Kota Kefamenanu. Struktur percakapan yang ditemukan meliputi gilir bicara, jeda, overlaps, backchannel, dan pasangan ajesensi.

Dalam penelitian ini, temuan gilir bicara didasarkan pada teori struktur percakapan yang dikemukakan oleh Yule. Yule (2006: 122) mengemukakan bahwa gilir bicara merupakan proses pergantian peran antara penutur dan petutur dalam suatu percakapan yang tidak terdapat rambu-rambu atau aturan. Artinya, setiap pemeran percakapan mempunyai hak yang sama untuk bertutur. Pada saat penutur berbicara dan tidak dapat menyesuaikan kontrol, maka petutur berhak mendapatkan gilir bicara tersebut. Berdasarkan teori tersebut, temuan dalam penelitian ini memenuhi terjadinya gilir bicara atau pergantian peran berbicara antara guru dengan siswa dalam pembelajaran Bahasa Indonesia di SMK se-Kota Kefamenanu. Gilir bicara dalam percakapan guru dengan siswa terjadi karena adanya kesempatan untuk bertutur dalam interaksi pembelajaran. Sistem gilir bicara yang terjadi telah dikenali dan disadari oleh guru maupun siswa.. Oleh karena itu, mereka sadar untuk mendapatkan giliran itu, menjaga, dan memberikan atau melepaskan giliran kepada lawan bicara.

Seperti halnya gilir bicara, jeda juga didasarkan pada teori struktur percakapan yang dikemukakan oleh Yule. Yule (2006: 125) mengemukakan bahwa kesenyapan dalam percakapan yang memungkinkan menandai adanya gilir bicara. Jeda dalam percakapan memiliki tiga bentuk yaitu jeda pendek, sedang dan panjang. Jeda pendek merupakan kesenyapan pendek sebagai bentuk keragu-raguan dan jeda panjang merupakan kesenyapan panjang. Berdasarkan teori tersebut, temuan dalam penelitian ini membuktikan bahwa dalam percakapan guru dengan siswa dalam pembelajaan Bahasa Indonesia di SMK seKota Kefamenanu terdapat jeda. Jeda dalam percakapan guru dengan siswa yang terjadi 
dalam interaksi pembelajaran Bahasa Indonesia adalah jeda panjang dan jeda pendek. Jeda panjang dan jeda pendek terjadi di tengah tuturan dan di akhir tuturan. Jeda di akhir tuturan menimbulkan jeda panjang, sedangkan jeda di tengah tuturan menimbulkan jeda pendek. Jeda panjang di akhir tuturan dalam pembelajaran Bahasa Indonesia disebabkan oleh tidak respons balik berupa tuturan dari petutur terhadap apa yang dibicarakan penutur. Jeda pendek di tengah tuturan dalam pembelajaran Bahasa Indonesia disebabkan oleh keraguraguan penutur dalam menyampaikan pesan. Keragu-raguan tersebut merupakan implikasi dari proses berpikir tentang sesuatu agar bisa disampaikan kepada petutur.

Overlaps didasarkan pada teori Yule. Yule (2006: 124) menjelaskan, overlaps adalah keadaan penutur dan petutur yang berbicara pada waktu bersamaan. Berdasarkan teori tersebut, temuan dalam penelitian ini membuktikan bahwa dalam percakapan guru dengan siswa dalam pembelajaan Bahasa Indonesia di SMK se-Kota Kefamenanu terdapat overlaps. Overlaps dalam percakapan guru dengan siswa terjadi karena tuturan atau penggunaan unsur lingual yang sama. Artinya, pada saat guru dengan siswa berbicara dalam waktu yang bersamaan, objek yang dibicarakan adalah objek yang sama dan dengan bahasa yang sama persis pula.

Backechanel juga didasarkan teori Yule (2006: 129) mengatakan bahwa respons yang diharapkan penutur kepada petutur (dapat berupa gerakan tubuh atau isyarat). Respons itu bisa berupa kata-kata seperti "ah-ha", "uh-huh", "yeah", anggukan, senyuman, ekspresi muka dan juga bisa gerak isyarat. Dengan adanya backchannel, penutur merasa bahwa petutur cukup memahami pembicaraanya. Berdasarkan teori tersebut, temuan dalam penelitian ini membuktikan bahwa dalam percakapan guru dengan siswa dalam pembelajaan Bahasa Indonesia di SMK se-Kota Kefamenanu terdapat backchannel. Backechanel yang terjadi dalam interaksi pembelajaran disebabkan oleh petutur memahami dan menerima atau menyetujui apa yang disampaikan penutur.

Bagian struktur percakapan yang terakhir adalah pasangan ajesensi. Pasangan ajesensi didasarkan teori Yule. Yule (2006: 132) menjelaskan bahwa pasangan ajesensi atau pasangan berdampingan adalah pola yang terjadi secara otomatis dalam percakapan dan selalu terdiri atas dua bagian yang diucapkan oleh pihak yang berbeda. Berdasarkan teori tersebut, temuan dalam penelitian ini membuktikan bahwa dalam percakapan guru dengan siswa dalam pembelajaan Bahasa Indonesia di SMK se-Kota Kefamenanu terdapat pasangan ajesensi. Pasangan ajesensi yang ditemukan disebabkan karena adanya salam sehingga langsung ada respons penerimaan salam, ada pertanyaan yang direspons dengan memberikan jawaban, dan ada permohonan yang direspons dengan pengabulan. Pada data yang terdapat pada bagian hasil penelitian, yang ditampilkan hanya data yang berkaitan dengan ucapan salam.

\section{SIMPULAN}

Penelitian ini membuktikan bahwa percakapan guru dengan siswa dalam interaksi pembelajaran Bahasa Indonesia di SMK se-Kota Kefamenanu menunjukan adanya giir bicara, jeda overlaps, backchannel, dan pasangan ajesensi. Gilir bicara dalam percakapan guru dengan siswa terjadi karena adanya kesempatan untuk bertutur dalam interaksi pembelajaran. Sistem gilir bicara yang terjadi telah dikenali dan disadari oleh guru maupun 
siswa. Jeda juga terdapat dalam percakapan guru dan siswa. Jeda yang muncul adalah jeda panjang dan jeda pendek yang terjadi di tengah tuturan dan di akhir tuturan. Jeda panjang terjadi akhir tuturan dan disebabkan oleh tidak adanya respons balik berupa tuturan dari petutur terhadap apa yang dibicarakan penutur. Jeda pendek terjadi di tengah tuturan dan disebabkan oleh keragu-raguan penutur dalam menyampaikan pesan. Overlaps dalam percakapan guru dengan siswa terjadi karena tuturan atau penggunaan unsur lingual yang sama. Backchanel yang terjadi dalam interaksi pembelajaran disebabkan oleh petutur memahami dan menerima atau menyetujui apa yang disampaikan penutur. Pasangan ajesensi yang ditemukan disebabkan karena adanya ucapan salam sehingga langsung ada respons penerimaan salam, ada pertanyaan yang direspons dengan memberikan jawaban, dan ada permohonan yang direspons dengan pengabulan.

\section{DAFTAR PUSTAKA}

Martyawati, Afritta Dwi. 2014. "Pasangan Berdampingan (Adjacency Pairs) dalam Lomba Ngapeh di Kutai Kartanegara”. PRASASTI. bttp:/ / dx.doi.org/10.20961/pras.v0i0.436.402

Purba, Antilan. 2002. Pragmatik Bahasa Indonesia. Medan: USU Press.

Purwoko, Herudjati. 2008. Discourse Analysis: Kajian Wacana bagi Semua Orang. Jakarta: Indeks.

Sudiana, I Nyoman. 2005. Interaksi Belajar Mengajar Bahasa dan Sastra Indonesia. Bali: Alfina Primata.

Trahutami, Sriwahyu Istana. 2012. "Struktur Pola Alih Tutur pada Percakapan AnakAnak". Humanika: Jurnal Ilmiah Kajian Humaniora Vol. 15 No. 9 Januari 2012. https:// doi.org/10.14710/humanika.15.9.

Yule, George. 2006. Pragmatik. Yogyakarta : Pustaka Belajar. Terjemahan dari Pragmatics. 